\title{
Alternative Strategy on Control of Postharvest Diseases of Mango (Mangifera indica L.) by Use of Low Dose of Ultraviolet-C Irradiation
}

\author{
Daniel Terao · João Sinézio de Carvalho Campos • \\ Eliane Aparecida Benato $\cdot$ Jorge Minoru Hashimoto
}

Received: 1 March 2014/Accepted: 15 July 2014/Published online: 21 August 2014

(C) Springer Science+Business Media New York 2014

\begin{abstract}
The demand for clean, safe and sustainable alternative control measures of postharvest diseases of fruit has increased in recent years, and the use of UV-C irradiation is a potential option. This study focused on evaluating UV-C dose effect on in vitro and in vivo development of fungi species and also on postharvest decay on mango cv. Tommy Atkins. The evaluated fungi which cause decay were as follows: Botryosphaeria dothidea, Lasiodiplodia theobromae, Alternaria alternata and Colletotrichum gloeosporioides. Fungus mycelium was exposed to increasing doses of UV-C irradiation: 0 (control), 2.0, 3.0, 5.0, 10.0 and $20 \mathrm{~kJ} \mathrm{~m}^{-2}$. L. theobromae and A. alternata received dose up to $59.7 \mathrm{~kJ} \mathrm{~m}^{-2}$. Mangos artificially inoculated with $B$. dothidea were treated with doses of UV-C irradiation: $0.0,0.5,1.0,2.5,5.0,7.5 \mathrm{e} 10.0 \mathrm{~kJ} \mathrm{~m}^{-2}$ and stored at $10{ }^{\circ} \mathrm{C}$ for 15 days and for 2 days at $22{ }^{\circ} \mathrm{C}$, observing the rot on daily basis. The trials were conducted in a completely
\end{abstract}

\section{Terao $(\square)$}

Embrapa Meio Ambiente, Empresa Brasileira de Pesquisa Agropecuária, Rod. SP-095, 340, Jaguariúna, SP 13820-000, Brazil

e-mail: daniel.terao@embrapa.br

J. S. de Carvalho Campos

Faculdade de Engenharia Química, Universidade Estadual de Campinas, Av. Albert Einstein, 500, Campinas,

SP CEP 13083-852, Brazil

\section{E. A. Benato}

Instituto Biológico, Agência Paulista de Tecnologia dos Agronegócios, Rod. Heitor Penteado, km 3, Campinas, SP CEP 13092-543, Brazil

\section{J. M. Hashimoto}

Embrapa Meio Norte, Empresa Brasileira de Pesquisa Agropecuária, Av. Duque de Caxias, 5650, Teresina, PI CEP 64.006-220, Brazil randomized design with six replicates for in vitro tests and four replicates with seven fruit as experimental unit. The in vitro trials demonstrated that even high dose of UV-C $\left(20 \mathrm{~kJ} \mathrm{~m}^{-2}\right)$ was not able to control the fungi development. Nonetheless, low dose of UV-C irradiation at $2.5 \mathrm{~kJ} \mathrm{~m}^{-2}$ controlled around $70 \%$ of fruit rot severity. Higher doses $\left(>5 \mathrm{~kJ} \mathrm{~m}^{-2}\right.$ ) caused damage on mango peel increasing the rot severity. Results suggest that, the application of low dose $\left(<3 \mathrm{~kJ} \mathrm{~m}^{-2}\right)$ of UV-C irradiation can contribute to the integrated management of postharvest diseases on mango, and that, the mechanisms of control involved are not directly related to the fungi development.

Keywords Nonthermal treatment - Integrated pest management $\cdot$ UV-C light

\section{Introduction}

In 2013, Brazil produced about 1.2 million tons of mangos and exported around 122,000 tons [1] and is considered the seventh biggest producer in the world, accounting for $3 \%$ of total mango production [11].

It is well known that during fruit development fungal infections occur, which remain quiescent within the tissue, with the possibility to develop and cause rot during transportation and storage, thus causing serious losses to producers and exporters of mangos. Therefore, to avoid the appearing of these diseases it has been used, preventive and indiscriminately, postharvest fungicides, contaminating the fruit.

Currently, consumers demand fruits free of chemical residues, due to the threat to human health which these synthetic products represent. Such situation has stimulated the scientific study of strategies for an alternative control of postharvest diseases. 
Among these strategies, the ultraviolet-C (UV-C) irradiation has demonstrated to be a potential when used in optimized or hormic doses, inducing favorable biological responses to conservation on the fruits, increasing the internal resistance of fruit tissue [10], as well as preserving the color and texture $[5,6]$.

However, the effect of UV-C treatment on mango has been little studied. In this sense, the present work focuses the evaluation of UV-C dose effect on in vitro development of fungi species causing postharvest decay on mangos and the optimization of the dosage and time of exposure to UV$\mathrm{C}$ irradiation on Tommy Atkins mangos to control postharvest disease without leaving toxic residues.

\section{Methodology}

The species of fungi studied in vitro were as follows: Botryosphaeria dothidea, Lasiodiplodia theobromae, Alternaria alternata and Colletotrichum gloeosporioides. Petri dishes containing the active fungi growth on PDA (Potato Dextrose Agar) medium were opened and received increasing doses of UV-C irradiation: 0 (control), 2.0, 3.0, $5.0,10.0$ and $20 \mathrm{~kJ} \mathrm{~m}^{-2}$. L. theobromae and A. alternata received dose up to $59.7 \mathrm{~kJ} \mathrm{~m}^{-2}$. After the treatments, the dishes were sealed and incubated under $25 \pm 2{ }^{\circ} \mathrm{C}$ and 12-h light dark ${ }^{-1}$ light regime, evaluating daily the fungi development, by measuring the mycelium growth.

The UV-C irradiation treatments were carried out in a UV-C prototype equipment which consisted of acrylic box with a reflecting surface at the top, one low-pressure germicidal lamp (Osram Puritec HNS, 36-watt and $253.7 \mathrm{~nm}$ wavelength emission peak). Mangos were placed $46 \mathrm{~cm}$ from the UV-C lamp for treatment, the light intensity was kept constant and the applied doses varied by modifying the exposure time. UV-C irradiation was measured using radiometer (UVx digital Newport Optical Power Meter, Model 1830C).

Mangos from commercial groves in the semiarid region of São Francisco River Valley (Pernambuco, Brazil) were previously disinfected with sodium hypochlorite solution and then rinsed in sterile distilled water. PDA disks, containing mycelium of $B$. dothidea in active growth, were deposited on the wound $(1 \times 2 \mathrm{~mm}$, deep $\times$ wide $)$ previously punctured along the equatorial region of each mango and afterward the inoculated fruits were kept in a moist chamber for $12 \mathrm{~h}\left(22 \pm 2{ }^{\circ} \mathrm{C}\right.$ e $100 \%$ of the relative humidity). The mangos samples received the following doses of UV-C: $0.5,1.0,2.5,5.0,7.5$ and $10.0 \mathrm{~kJ} \mathrm{~m}^{-2}$. During the irradiation, fruits were individually rotated on their longitudinal axis to expose the two separated sides of mangos to the same UV-C dose. After exposure to UV-C, fruits were packed in cardboard boxes, protected from light and stored for 15 days under refrigeration $\left(10 \pm 2{ }^{\circ} \mathrm{C}\right.$ and $80 \pm 2 \%$ of the relative humidity) and then 2 days in ambient conditions $\left(22 \pm 2{ }^{\circ} \mathrm{C}\right.$ and $70 \pm 2 \%$ relative humidity). The severity of the disease was evaluated by measuring the size of lesions on alternated days for the fruits stored under refrigeration and daily for those stored at room temperature. The experiments were conducted using six replicates for the in vitro essays and four replicates with seven fruits per set for the in vivo essay.

\section{Results and Discussion}

Effect of UV-C on Mycelial Growth Rate of Mango Postharvest Pathogens

As a whole, it was observed that, within the range of evaluated doses, UV-C irradiation did not inhibit mycelial growth of mango fungi.

For the species C. gloeosporioides and B. dothidea, there was a decreasing trend in the rate of mycelial growth with increasing doses of UV-C applied. However, to $A$. alternata a curious fact occurred, in which higher doses of UV-C evaluated, appear to have stimulated the development of this fungus. In the case of $L$. theobromae, it was observed a similar behavior and a decreasing trend in the rate of growth from a dose of $59.7 \mathrm{~kJ} \mathrm{~m}^{-2}$ (Fig. 1).

A similar result was obtained by Cia et al. [10], using UV-C irradiation in doses of $0.4-2.4 \mathrm{~kJ} \mathrm{~m}^{-2}$, with a fungicidal effect on $C$. gloeosporioides, but accelerated sporulation at $2.4 \mathrm{~kJ} \mathrm{~m}^{-2}$. Basseto et al. [3] observed that the mycelial growth of Monilinia fructicola was stimulated at doses: $0.26,0.52,3.13$ and $5.22 \mathrm{~kJ} \mathrm{~m}^{-2}$, observing partial inhibition at $10.44 \mathrm{~kJ} \mathrm{~m}^{-2}$. At this dose, a similar effect was caused on Rhizopus stolonifer, decreasing the development and a complete inhibition was observed at $31.32 \mathrm{~kJ} \mathrm{~m}^{-2}$. Sharma and Tripathi [15] found that germination of conidia Fusarium oxysporum f. sp. Gladioli was inhibited gradually by UV-C doses of $0.37,0.56,0.84$, 1.32 and $2.44 \mathrm{~kJ} \mathrm{~m}^{-2}$, and total inhibition at higher doses $\left(3.63,4.98\right.$ and $\left.7.59 \mathrm{~kJ} \mathrm{~m}^{-2}\right)$.

The UV-C Irradiation Effect on the Control of Rot Caused by $B$. dothidea on 'Tommy Atkins' Mango

The UV-C irradiation applied on the inoculated mangos showed that lower doses $\left(0.5-2.5 \mathrm{~kJ} \mathrm{~m}^{-2}\right)$ had more satisfactory level of control of $B$. dothidea than higher doses. The mangos treated with $2.5 \mathrm{~kJ} \mathrm{~m}^{-2}$, stored under refrigeration for 15 days and more 2 days under ambient conditions, showed a level of control of rot around $70 \%$ (Table 1). 

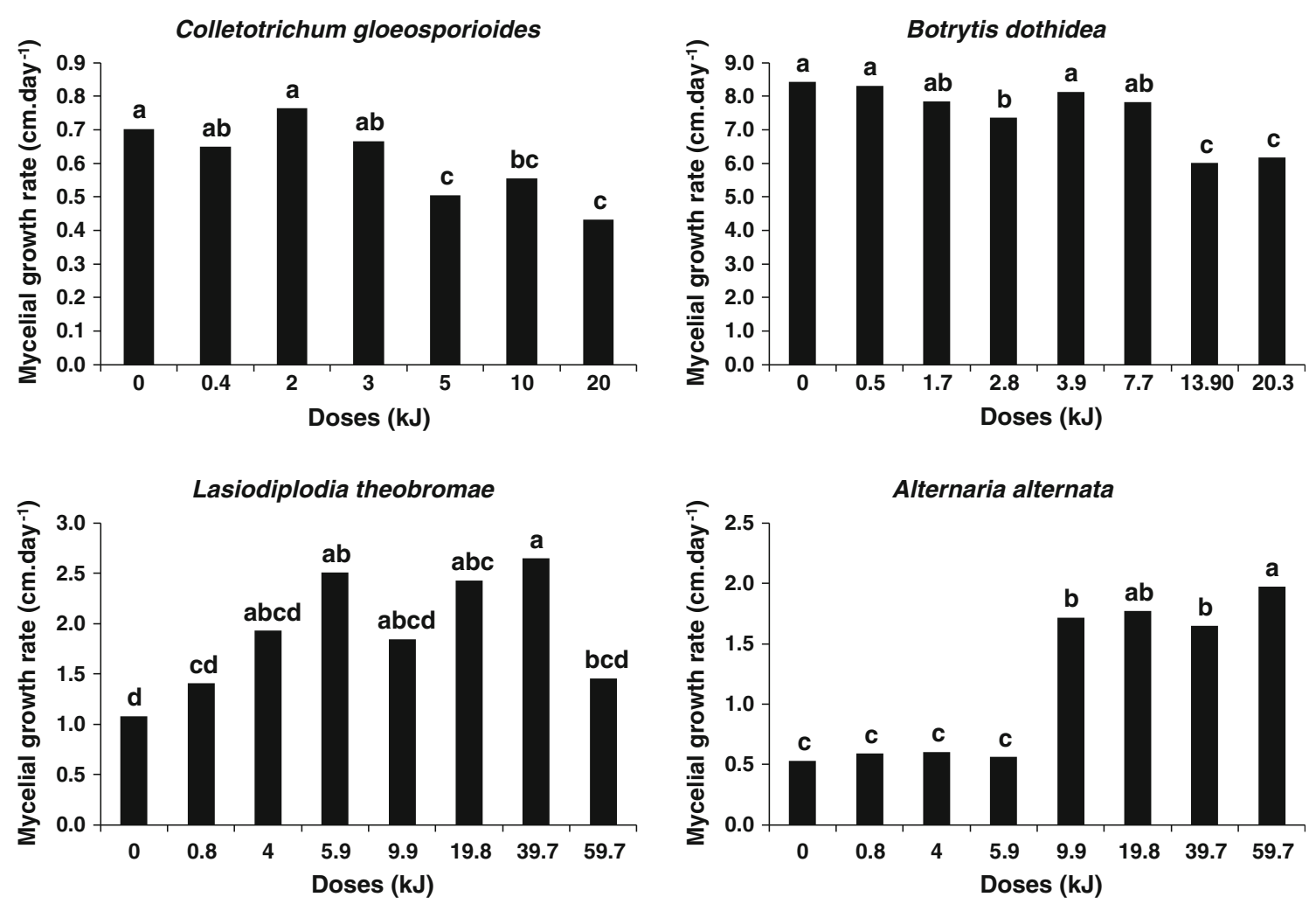

Fig. 1 Effect of UV-C irradiation on mycelial growth rate of postharvest pathogens of mango

Table 1 Severity $(\mathrm{mm})$ of Botryosphaeria dothidea infection and percentage (\%) of control on inoculated 'Tommy Atkins' mango, submitted to UV-C treatment and stored for 15 days at $10^{\circ} \mathrm{C}$ and then 2 days at $22{ }^{\circ} \mathrm{C}$

$\mathrm{Z}$ Means followed by the same
letter in the column do not differ
significantly (Tukey, $p \leq 0.05$ ).
Mean of four replications

Research has demonstrated this beneficial effect generated by the application of low doses of UV-C in various fruits, inducing hormesis and subsequent formation of resistance mechanisms and antifungal metabolites in the plant tissue. Khademi et al. [13] administered doses of $1-10 \mathrm{~kJ} \mathrm{~m}^{-2}$ on persimmon and observed that the optimal range for the induction of resistance against the disease is between 1.5 and $3 \mathrm{~kJ} \mathrm{~m}^{-2}$. However, the optimal dose to be recommended will depend on the microorganism to be controlled and species of the fruit [14].

Another factor to be considered is the fruit surface tissue damage caused by UV-C irradiation. Up to a dose of $2.5 \mathrm{~kJ} \mathrm{~m}^{-2}$, the damage was nonexistent or very slight, however, higher doses caused more pronounced browning, which should have favored the further development of the pathogen. It was observed that rotating the fruit during application and keeping them in the dark for $1 \mathrm{~h}$ after irradiation, as recommended by Stevens et al. [16], contributed for a better tolerance of the mango skin to UV-C irradiation.

These results suggest that low doses of UV-C irradiation may have contributed to control the infection of mango by B. dothidea, slowing the development of the pathogen by inducing resistance mechanisms on fruit against postharvest diseases.

Similar results were observed with UV-C irradiation on 'Italy' grape, reducing Botrytis cinerea infection, $C$. 
gloeosporioides on 'Niagara Rosada' grape and Colletotrichum sp. on 'Kumagai' guava [9].

Bartinick et al. [2] recommend low doses of UV-C irradiation $\left(0.375 \mathrm{~kJ} \mathrm{~m}^{-2}\right)$, on apple when combined with hot water brushing at $50{ }^{\circ} \mathrm{C}$ for $15 \mathrm{~s}$, to control Cryptosporiopsis. perennans.

The effect of low doses of UV-C reported on the control of potato, onion, grapefruit, mandarin and apple postharvest pathogens, demonstrated that the treatment with UV-C irradiation has a direct action against microorganisms, and also can induce reactions improving resistance to pathogens, lessening the fruit rot development $[4,16]$.

Charles et al. [7] exposing tomatoes to hormic dose of UV-C $\left(3.7 \mathrm{~kJ} \mathrm{~m}^{-2}\right)$ aiming the control of B. cinerea found that, immediately after the irradiation, there was an increased susceptibility to disease, but then, a gradual increase in resistance was observed due to accumulation of rishitin (sesquiterpene phytoalexin), reaching maximum concentration $(46.23 \mathrm{mg} / \mathrm{kg})$ at 15 days, declining to $3.5 \mathrm{mg} / \mathrm{kg}$ at 35 days.

The physico-chemical characteristics evaluated after 15 days of storage of fruit presented in Tables 2, 3, basically indicate that the application of UV-C did not affect the fruit quality significantly.
A criterion for the selection of fruit is the appearance of the epidermis, i.e., discoloration and darkening. Such characteristics can be evaluated by the lightness (L).

According to the results shown in Table 3, fruit exposed to doses from $5.0 \mathrm{~kJ} \mathrm{~m}^{-2}$ exhibited significantly lower lightness values than when exposed to lower doses and control, indicating the occurrence of the skin browning, which can make the fruit more vulnerable to the attack by fungi causing postharvest diseases. Charles et al. [8] indicated that UVC changed the amount and ultra structure of the epicuticular wax in tomato due to changes in chemical composition and that this may affect the surface reflectance characteristics. Khademi et al. [13] observed a decrease of $\mathrm{L}^{*}$ (lightness) in persimmon, immediately after UV-C treatment $\left(1.5\right.$ and $3 \mathrm{~kJ} \mathrm{~m}^{-2}$ ) related to a mild initiation of darkening on the fruit surface, interrupted during storage at low temperature. In preliminary tests, Khademi et al. [13] used doses of $0-10 \mathrm{~kJ} \cdot \mathrm{m}^{-2}$, but small doses of UV-C caused low discoloration and darkening, satisfying the criteria for fruits selection. Gonzales-Aguilar et al. [12] stated that high doses of UV-C cause peel damage, accelerating the Tommy Atkins mango deterioration.

The results of this research confirm that hormetic doses of UV-C irradiation represent a potential means to control
Table 2 'Tommy Atkins' mango physico-chemical quality attributes 15 days after UV-C treatment
${ }^{\mathrm{z}}$ Means followed by the same letter in the column do not differ significantly of the Turkey test

Table 3 Color parameters of the peel and pulp of 'Tommy Atkins' mango 15 days after UV-C irradiation
${ }^{\mathrm{z}}$ Means followed by the same letter do not differ significantly of the Tukey test

\begin{tabular}{llllll}
\hline $\begin{array}{l}\text { Treatment } \\
\left(\mathrm{Kj} \mathrm{m}^{-2}\right)\end{array}$ & $\mathrm{pH}$ & $\begin{array}{l}\text { Firmness } \\
\text { pulp (N) }\end{array}$ & $\begin{array}{l}\text { Total soluble } \\
\text { solids }(\%)\end{array}$ & $\begin{array}{l}\text { Titratable acidity } \\
(\text { mg citric acid/ } \\
100 \mathrm{ml} \text { of juice })\end{array}$ & Ratio \\
\hline 0.0 & $3.49 \mathrm{a}^{\mathrm{z}}$ & $29.39 \mathrm{a}$ & $11.14 \mathrm{ab}$ & $0.64 \mathrm{a}$ & $23.56 \mathrm{a}$ \\
0.5 & $3.47 \mathrm{a}$ & $38.72 \mathrm{a}$ & $11.88 \mathrm{a}$ & $0.66 \mathrm{a}$ & $25.95 \mathrm{a}$ \\
1.0 & $3.54 \mathrm{a}$ & $11.61 \mathrm{a}$ & $11.07 \mathrm{ab}$ & $0.49 \mathrm{a}$ & $24.52 \mathrm{a}$ \\
2.5 & $3.40 \mathrm{a}$ & $16.76 \mathrm{a}$ & $10.04 \mathrm{~b}$ & $0.64 \mathrm{a}$ & $16.74 \mathrm{a}$ \\
5.0 & $3.70 \mathrm{a}$ & $20.67 \mathrm{a}$ & $12.2 \mathrm{a}$ & $0.45 \mathrm{a}$ & $33.39 \mathrm{a}$ \\
7.5 & $3.42 \mathrm{a}$ & $6.37 \mathrm{a}$ & $11.35 \mathrm{ab}$ & $0.66 \mathrm{a}$ & $19.52 \mathrm{a}$ \\
10.0 & $3.67 \mathrm{a}$ & $16.55 \mathrm{a}$ & $11.22 \mathrm{ab}$ & $0.65 \mathrm{a}$ & $18.16 \mathrm{a}$ \\
$\mathrm{C} . \mathrm{V}$. & 9.79 & 58.97 & 10.28 & 11.42 & 23.15 \\
$\mathrm{~F}$ & $\mathrm{NS}$ & $\mathrm{NS}$ & $*$ & $\mathrm{NS}$ & $\mathrm{NS}$ \\
\hline
\end{tabular}

\begin{tabular}{lllllll}
\hline $\begin{array}{l}\text { Treatment } \\
\left(\mathrm{kJ} \mathrm{m}^{-2}\right)\end{array}$ & L pulp & L peel & C pulp & C peel & h pulp & h peel \\
\hline 0.0 & $72.64 \mathrm{a}^{\mathrm{z}}$ & $55.30 \mathrm{a}$ & $59.46 \mathrm{a}$ & $27.03 \mathrm{a}$ & $89.03 \mathrm{a}$ & $77.58 \mathrm{a}$ \\
0.5 & $72.70 \mathrm{a}$ & $52.66 \mathrm{a}$ & $58.57 \mathrm{a}$ & $23.88 \mathrm{a}$ & $90.11 \mathrm{a}$ & $83.54 \mathrm{a}$ \\
1.0 & $71.51 \mathrm{a}$ & $56.20 \mathrm{a}$ & $58.44 \mathrm{a}$ & $28.01 \mathrm{a}$ & $90.92 \mathrm{a}$ & $79.61 \mathrm{a}$ \\
2.5 & $73.87 \mathrm{a}$ & $52.83 \mathrm{a}$ & $55.99 \mathrm{a}$ & $25.40 \mathrm{a}$ & $90.50 \mathrm{a}$ & $85.36 \mathrm{a}$ \\
5.0 & $68.57 \mathrm{a}$ & $47.33 \mathrm{~b}$ & $61.20 \mathrm{a}$ & $20.14 \mathrm{a}$ & $89.26 \mathrm{a}$ & $68.18 \mathrm{a}$ \\
7.5 & $71.62 \mathrm{a}$ & $45.90 \mathrm{~b}$ & $60.84 \mathrm{a}$ & $18.90 \mathrm{~b}$ & $89.70 \mathrm{a}$ & $69.22 \mathrm{a}$ \\
10.0 & $68.20 \mathrm{a}$ & $50.07 \mathrm{~b}$ & $62.42 \mathrm{a}$ & $21.92 \mathrm{a}$ & $87.53 \mathrm{a}$ & $69.39 \mathrm{a}$ \\
$\mathrm{C} . \mathrm{V}$. & 5.83 & 5.98 & 8.88 & 22.15 & 3.43 & 16.10 \\
$\mathrm{~F}$ & $\mathrm{NS}$ & $* *$ & NS & $* *$ & NS & $*$ \\
\hline
\end{tabular}


postharvest diseases of mango by improving natural defense, extending the shelf-life and keeping the sensorial characteristics of the fruit.

Acknowledgments The authors wish to thank the São Paulo Research Foundation (Fundação de Amparo à Pesquisa do Estado de São Paulo-FAPESP: 2011/23432-8) for financial support for this research.

\section{References}

1. Alice Web Mercosul (2014). http://www.alicewebmercosul.mdic. Accessed July 8

2. Bartinick VA, Valdebenito-Sanhueza RM, Amarante CVT, Castro LAS, Rizzatti MR, Souza JAV (2010) Água aquecida e radiação UV-C no controle pós-colheita de Cryotosporiopsis perennans em maçã. Pesqui Agropecu Bras 45(2):124-131

3. Basseto E, Amorim L, Benato EA, Gonçalves F, Lourenço SA (2007) Effect of UV-C irradiation on postharvest control of brown rot (Monilinia fructicola) and soft rot (Rhizopus stolonifer) of peaches. Fitopatol Bras 32(5):393-399

4. Brown JE, Lu TY, Stevens C, Khan VA, Lu JY, Wilson CL, Collins DJ, Wilson MA, Igwegbe ECK, Chalutz E, Droby S (2001) The effect of low dose ultraviolet light-C seed treatment on induced resistance in cabbage to black rot (Xanthomonas campestris pv. campestris). Crop Prot 20(10):873-883

5. Bu J, Ni Z, Aisikaer G, Jiang Z, Khan ZU, Mou W, Ying T (2014) Postharvest ultraviolet-C irradiation suppressed Psy 1 ans Lcy- $\beta$ expression and altered color phenotype in tomato (Solanum lycorpesicum) fruit. Postharvest Biol Technol 89:1-6

6. Bu J, Yu Y, Aisikaer G, Ying T (2013) Postharvest UV-C irradiation inhibits the production of ethylene and the activit of cell wall-degrading enzimes during softening of tomato (Lycopersicon esculentum L.) fruit. Postharvest Biol Technol 86:337-345
7. Charles MT, Benhamou N, Arul J (2008) Physiological basis of $\mathrm{UV}-\mathrm{C}$ induced resistance to Botrytis cinerea in tomato fruit. III. Ultrastructural modification and their impact on fungal colonization. Postharvest Biol Technol 47(1):27-40

8. Charles MT, Makhlouf J, Arul J (2008) Physiological basis of UV-C induced resistance to Botrytis cinerea in tomato fruit: II. Modification of fruit surface and changes in fungal colonization. Postharvest Biol Technol 47(1):21-26

9. Cia P (2009) Tecnologias para o manuseio de doenças pós-colheita de produtos hortícolas. In: XLII Congresso Brasileiro de Fitopatologia. Tropical Plant Pathol, 34: XXV-XXVI

10. Cia P, Pascholati SF, Benato EA, Camili EC, Santos CA (2007) Effects of gamma and UV-C irradiation on the postharvest control of papaya anthracnose. Postharvest Biol Technol 43(3):366-373

11. FAO (2014). Food and Agriculture Organization of the United Nations. http://www.fao.org/corp/statistics Accessed July 8

12. Gonzales-Aguilar GA, Wang CY, Buta JG, Krizek DT (2001) Use of UV-C irradiation to prevent decay and maintain postharvest quality of ripe 'Tommy Atkins' mangoes. Int J Food Sci Technol 36(7):767-773

13. Khademi O, Zamani Z, Poor Ahmadi E, Kalantari S (2013) Effect of UV-C radiation on postharvest physiology of persimmon fruit (Diospyros kaki Thunb.) cv. "Karaj" during storage at cold temperature. Int Food Res J 20(1):247

14. Schenk M, Guerrero S, Alzamora SM (2008) Response of some microorganisms to ultraviolet treatment on fresh-cut pear. Food Bioprocess Tech 1:384-392

15. Sharma N, Tripathi A (2008) Integrated management of postharvest Fusarium rot of gladiolus corms using hot water, UV-C and Hyptis suaveolens (L.) Poit. Essential oil. Postharvest Biol Technol 47(2):246-254

16. Stevens C, Liu J, Khan VA, Lu JY, Kabwe MK, Wilson CL, Igwegbe ECK, Chalutz E, Droby S (2004) The effects of lowdose ultraviolet light-C treatment on polygalacturonase activity, delay ripening and Rhizopus soft rot development of tomatoes. Crop Protect 23(6):551-554 